\title{
Tocopherol contents of vegetables and fruits
}

\author{
BY V. H. BOOTH* AND M. P. BRADFORD \\ Dunn Nutritional Laboratory, University of Cambridge and Medical Research Council
}

(Received I9 March 1963)

Values for the 'vitamin E' contents of some vegetables and fruits have been published, for example by Emmerie \& Engel (1943) and Harris, Quaife \& Swanson (1950). The values given by these and other authors may have been in error for various reasons. For example, neither seasonal fluctuation nor variation in anatomical distribution was fully recognized. Moreover, the analytical results obtained by chemical means are suspect for two other reasons. Firstly, tocopherol would have been lost, enzymically through chopping or macerating leaves before extraction (Booth, $1962 b$ ), or through heat, alkali or the action of Floridin earth (Booth, 196I) or other adsorbent used in the preparation and purification of extracts. Secondly, it is now clear that reducing substances other than tocopherols would have been included in the $\mathrm{FeCl}_{3}-$ dipyridyl test. These and other limitations have recently been discussed, and a simpler procedure for determining tocopherols in plant tissues has been proposed (Booth, I $963 a$ ). The results of analyses by the new procedure are presented in this paper.

\section{METHODS}

Materials. The vegetables and fruits were obtained either from the market or from local gardens, and were analysed without delay. Batches differed from one another as to variety, location or date. Materials (such as parsley) that were available over a wide season were analysed in different months.

Sampling. An attempt was always made to analyse the 'edible portion'. Since there is much more tocopherol in dark-green than in pale or colourless parts (Booth, $1963 b$ ), and, since the dark-green parts of such materials as brassicae and leeks are variously discarded, the selection presented opportunities for variation. Opinions on demarcation were sought from housewives, whose suggestions were applied when vegetables were trimmed. Yellow senescent leaves, which are much richer in tocopherol than growing leaves (Booth \& Hobson-Frohock, 196r) but are dietetically unattractive, were completely discarded.

Tocopherol determination. Materials were analysed raw. The effect on the $\alpha$-tocopherol contents of cooking vegetables by boiling is only slight (Booth \& Bradford, 1963) in comparison with other variables, provided the vegetable is suddenly immersed in vigorously boiling water. Small samples were carefully cut with scissors, or with a sharp knife on a damp block of wood, weighed in duplicate or in triplicate, and immediately extracted at room temperature with cold acetone and light petroleum

- Member of the scientific staff of the Agricultural Research Council. 
(Booth, 1959). Without saponification or other pretreatment the extracts were applied to filter-paper that had been treated with $\mathrm{ZnCO}_{3}$ (Green, Marcinkiewicz \& Watt, I955) and fluorescein (Analytical Methods Committee, 1959). Chromatograms were developed in two dimensions, then examined under u.v. irradiation, which made individual tocopherols visible as dark spots. The tocopherols were cut out and determined with the $\mathrm{FeCl}_{3}$-dipyridyl reagent. The method has been described in full elsewhere (Booth, I963a). The coefficient of variation of a mean of duplicates was about $\pm 6 \%$ for materials having tocopherol contents > I p.p.m.

Materials marked with a $\rfloor$ in Table $I$ were assayed in this laboratory by Dr R. J. Ward before the present method was available. He extracted the samples with acetone, saponified the extracts, chromatographed them first on Floridin earth and then on paper in two dimensions as described by the Analytical Methods Committee (1959).

Dry matter. This was calculated from the weights of samples before and after heating at $100^{\circ}$ for $5 \mathrm{~h}$.

\section{RESULTS}

\section{The best estimate}

The value that is wanted is the $\alpha$-tocopherol content of the material at the stage of maturity when it is most likely to be used for human consumption. Our estimate of this value is provided by the general mean of the determinations. These mean values, and the numbers of batches on which they were based, are shown in Table I. Some of the means are based on only few batches: these are in general uncommon materials or foods too weak in tocopherol to contribute much to the diet.

\section{Materials tested}

Division into groups has been made according to dietary, rather than botanical, considerations. For example, rhubarb is placed under Fruits.

Explanatory notes on certain items in Table I are given below. Tocopherol contents are based on dry matter and (in parentheses) on fresh weight: they are expressed in p.p.m.

Apple. Most of the tocopherol was in the skin. Therefore values are given separately for flesh only, and for the whole fruit without core. Dark-green cooking apples had more tocopherol than red or yellow dessert types.

Blackberries. The fruits contained more $\gamma$ - and $\delta$ - than $\alpha$-tocopherol. The wild variety had $\gamma 300$ (47), $\delta 270$ (45); the cultivated had $\gamma 85$ (I I), $\delta 80$ (Io).

Broccoli, sprouting. In both purple and white there was only a small amount of tocopherol in the flower, more in small leaf and much more in large leaf. The value for the edible portion therefore depends upon the proportion of leaf that is included. An edible sample, from sprouting broccoli harvested in March, comprised $40 \%$ flower, $40 \%$ leaf and $20 \%$ stem.

Brussels sprouts. The $\alpha$-tocopherol content of $45(6)$, observed in November and December while the sprouts were still growing, rose to $160(20)$ in January and February, when the growth rate would have been low. 
Table I. The 'best estimate', under average conditions, of the $\alpha$-tocopherol content of the edible portion of fresh vegetables and fruits

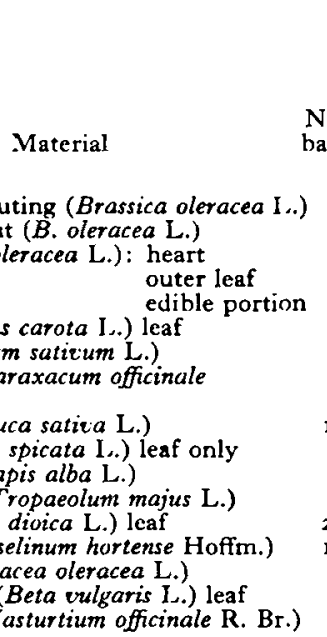

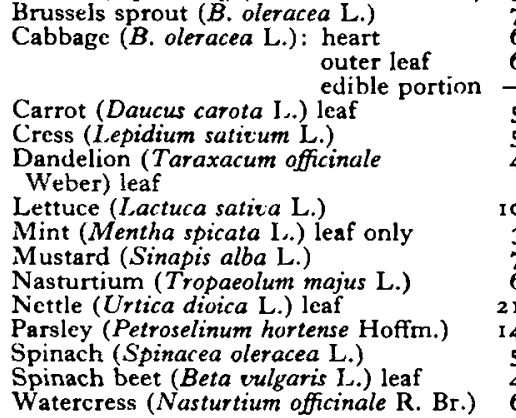

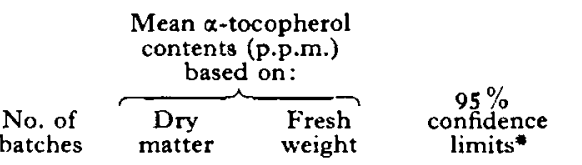

Remarks

Artichoke (Helianthus tuberosus L.)

Asparagus (Asparagus officinalis L.)

Bean, broad (Vicia Faba L.)

Bean, dwarf or french (Phaseolus

vulgaris L.)

Bean, runner ( $P$. coccineus L.)

Beetroot (Beta vulgaris L.)

Carrot (Daucus carota L.) root

Cauliflower (Brassica oleracea L.)

Celery (Apium graceolens L.): $\begin{gathered}\text { stalk } \\ \text { leaf }\end{gathered}$

Cucumber (Cucumis satizus L.): Leafy vegetables

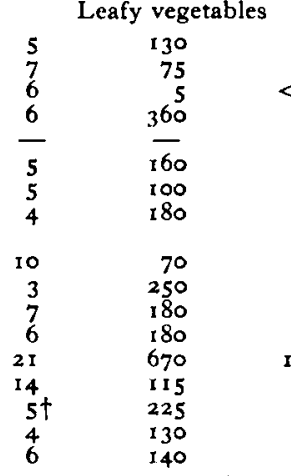

Other vegetables

\begin{tabular}{rrl}
20 & $70-250$ & \\
10 & $45-125$ & $\overline{-}$ \\
$<1$ & $3-10$ & Feb., Mar. \\
60 & $205-630$ & Dec.-Mar. \\
\hline- & - & See p. 578 \\
30 & $85-300$ & \\
7 & $50-185$ & Maweeks \\
25 & $90-360$ & Mar., May, Sept.
\end{tabular}

flesh only

whole

Leek (Allium porrum L.)

Mushroom (Psalliota campestris (L.) Fr.)

Onion (Allium cepa L.)

Parsnip (Pastinaca sativa L.) -

Pea (Pisum sativum L.)

Potato (Solanum tuberosum L.) tuber

Radish (Raphanus sativus L.)

Swede (Brassica napus L.) root

Turnip ( $B$. rapa $L$.) root

Apple (Pyrus malus L.):

fiesh only

flesh and skin

Blackberry (Rubus fruticosus L.):

wild

cultivated

Blackcurrant (Ribes nigrum L.)

Cherry (Prunus avium L.)

Damson $(P$. instititia L.)

Gooseberry (Ribes grossularia L.)

Melon (Cucumis melo L.) flesh

Pear (Pyrus comuris L.): flesh

Raspberry (Rubus idaeus L.) flesh and skin

Redcurrant (Ribes rubrum L.)

Rhubarb (Rheum hybridum Murray)

Strawberry (Fragaria ananassa

Duchesne)

Tomato (Lycopersicum esculentum Mill.)

3
3
1
3
2
1
7
6
3
1
2
3
8
2
4
2
3
2
3
3
2

$\begin{array}{cc}760 & 1 \cdot 5 \\ 4 & 25 \\ 10 & 0.5 \\ 5 & <1 \\ \frac{5}{50} & \text { nd } \\ 15 & 5 \\ 30 & 1 \cdot 5 \\ 50 & 2 \\ <5 & <1 \\ 20 & 1 \\ 95 & \text { 10 } \\ 3 & \ll 1 \\ <1 & \ll 1 \\ 60 & \text { 10 } \\ - & \text { nd } \\ \text { 1 } & <1 \\ - & \text { nd } \\ - & \text { nd } \\ - & \text { nd } \\ \text { Fruits } & \end{array}$

$45^{-110}$

$105-300$

$105-320$

$495-920$

$495-920$
$80-165$

$120-420$

$65-260$

$80-250$
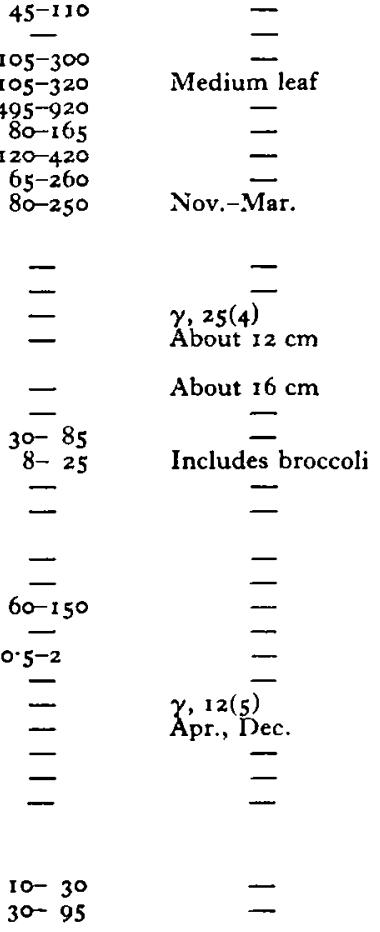

\begin{tabular}{|c|c|c|c|c|}
\hline $6+$ & 18 & 2 & $10-30$ & 一 \\
\hline $5 t$ & $5^{\circ}$ & 5 & $30-95$ & - \\
\hline 2 & 210 & 35 & 一 & Also $\gamma$ and $\delta$ \\
\hline 3 & 45 & 6 & - & See p. 576 \\
\hline If & 一 & 10 & - & 一 \\
\hline If & - & $1 \cdot 3$ & - & - \\
\hline $\begin{array}{l}x \\
6 \delta\end{array}$ & 40 & 7 & - & 一 \\
\hline 68 & 40 & 4 & $23-70$ & - \\
\hline $3+$ & 15 & $<1$ & 二 & 二 \\
\hline $3 \dagger$ & 30 & 5 & 一 & 二 \\
\hline It & 一 & 3 & 一 & Also $\gamma$ and $\delta$ \\
\hline If & - & I & 一 & - \\
\hline 3 & 35 & 2 & - & - \\
\hline If & 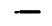 & $2 \cdot 2$ & - & - \\
\hline
\end{tabular}

For meaning of values in last column see paragraph on 'explanatory notes', p. 576.

nd, none detected under our conditions, which would usually imply $<0.3$ p.p.m. fresh weight.

- Expressed in p.p.m. dry matter. They span the range within which $95 \%$ of the values would be expected to lie under our conditions.

$t$ Including one batch assayed by Dr R. J. Ward.

I Assayed by Dr Ward. See text, under tocopherol determination.

Including two batches assayed by Dr Ward. 
Cabbage. The tocopherol in the almost colourless heart of different varieties of cabbage was sometimes barely detectable, whereas the concentration was high in the green outer leaves. Values for both are given in Table I. The $\alpha$-tocopherol contents, at different sites on one large leaf in February, were: purple edge $360(65)$; light-green near rib 170 (22); green near base 60 (8). Values for the edible portion, as selected by different observers, from two batches in October were $25(2)$ and $<5$ respectively. In December four observers trimmed one cabbage each, and the four cabbages were analysed separately. The $\alpha$-tocopherol contents were $6(<\mathrm{I}), 8(<\mathrm{I}), 5^{\circ}(5), 65(7)$. Because the value for an edible portion depends upon the proportion of outer leaf that is included, and because the variation from all causes is so great, the tocopherol content of 'cabbage' might be anywhere between 5 and 100 . A value around 50 (10) is tentatively suggested.

Carrot. Five varieties of spring-sown carrots were examined between August and April. One batch of 'white' or fodder carrots had ro (I) but it is not included in 'Table I. Leaves are included because they may be used as 'parsley'.

Cauliflower and broccoli. Values have been pooled. No tocopherol was detected in the flower of either. The smaller leaf, of the type frequently cooked with the flowerhead, had in October $40(3.5)$, in November 120 (I5) and in March 140 (I6). The edible portions, as selected by different observers who retained different amounts of leaf, had tocopherol contents ranging from $I$ to $3^{\circ}$.

Celery. Pale-green edible leaves had an $\alpha$-tocopherol content of $5^{\circ}(7)$. Pale-green stalks had $5^{\circ}(3)$, white stalks had I5 (I). The mean for white and pale-green stalks taken together is reported in Table $\mathbf{I}$, darker-green stalks having been discarded.

Cress. September-sown garden cress had an appreciably higher tocopherol content than that grown in March.

Cucumber. The tocopherol was almost entirely in the skin. Values are therefore given separately for the flesh and for the whole cucumber.

Dandelion. The $\alpha$-tocopherol content of leaf in September was nearly fourfold that in March, and was intermediate in value in May.

Leek. A steep concentration gradient was observed in a batch of leeks in December, from the green leafy top with 800 (95) to the almost colourless base with $55(5)$. The value for the edible portion of this batch was $250(30)$, but the $\alpha$-tocopherol contents of other batches ranged down to 25 (2).

Lettuce. The batches included different varieties of cos and cabbage types grown outdoors from May to October. The outer leaves contained more tocopherol than the inner leaves. The tocopherol content of the edible leaves ranged from barely detectable in two batches to 190 ( 10 ) in one batch. The water content of lettuce leaves averaged $93.3 \%$, an unusually high value for a leafy vegetable.

Mint. The value given is for leaf only. Because the stem contains much less tocopherol, if the edible portion contains appreciable stem the value is correspondingly lower.

Mustard. The leaf and stem of young plants as used for salad were analysed, and batches were taken from those grown both outdoors and under glass. The leaf had five times the tocopherol content of the stem. Therefore the value for the edible portion 
depends upon how the plant is harvested. In our samples leaf and stem were approximately equal in weight. Tocopherol contents were 190 (20) in April and November but only $5^{\circ}(5)$ in summer, when the plants were growing fast (ready in less than 12 days).

Nasturtium. The concentration in leaves $9 \mathrm{~cm}$ wide was twice that in leaves $2.5 \mathrm{~cm}$ wide. October leaves had three times the concentration found in July leaves. In senescent leaves the tocopherol content rose to 960 (100), but such leaves are not represented in Table $\mathrm{I}$.

Nettle. Leaves of the stinging nettle are included in the survey because they are sometimes cooked and eaten as 'spinach'. The tocopherol values varied from $24^{\circ}(50)$ in March, through 1070 (215) in June-July to $55^{\circ}$ (105) in November. The pooled standard deviation within months was little more than half the overall standard deviation.

Parsley. Stems were low in tocopherol. Leaves, together with petioles and the thinnest stems, were analysed, with these results: July 75 (I I); September II 5 (17); November-December 130 (22).

Radishes. One batch of winter radish-variety China Rose-was included.

Raspberry. The fruit contained $\gamma$-tocopherol I5 and $\delta$-tocopherol 27, both based on fresh weight.

Tomato. The fruits were grown locally. They were not peeled.

Watercress. The tocopherol content of leaf was four times that of stalk. An edible portion, as selected here, contained $50-60 \%$ of stalk.

\section{DISCUSSION}

\section{Variability}

A noticeable feature of the results is the considerable variation in the tocopherol values, not only between species but also within a species or a variety. Experimental error contributed only a small amount of the overall variation, but a larger contribution came from unequal anatomical distribution of tocopherol, richer 'inedible' parts being variously discarded. The tocopherol content increased with the maturity of the tissue, the value in batches of old material often exceeding twice that in young material. Even when these factors were controlled, by analysing for example nettle leaf on successive days, a variation remained, due presumably to varying intensity of sunlight, soil state and other growing conditions at the time of harvest.

The proportional variation within all varieties was similar. A pooled measure of variation was therefore calculated from the logarithms of individual batch assays, whence upper and lower confidence limits at $95 \%$ probability were calculated for all materials for which four or more batches have been assayed.

\section{Application of findings}

Therefore, although Table I may be used for calculating the approximate tocopherol contents of standard diets, these sources of variation must be borne in mind in assessing the accuracy of the computed contents. All dietary components of food are subject to variation (McCance \& Widdowson, I960), and the results now presented show that 
this condition applies in particularly high degree to tocopherol in vegetables. In fact the results support the thesis that there is no precise typical value for the tocopherol concentration in a given plant.

Another noticeable feature, of these and other published results, is that tocopherol concentrations are high in dark-green tissues, moderate in fast-growing leaves, lightgreen tissues and coloured fruits, and low in roots, etiolated tissues and colourless fruits. Application of these rules enables a rough prediction to be made for other materials.

The materials were obtained 'in season', with only few exceptions were grown outdoors, and were analysed shortly after harvesting. When leaves die or cease growing, the tocopherol concentration rises, the rise being absolute and not due to loss of water or solids. Hence vegetables past their prime, or grown under adverse conditions, or that have wilted, may have different, probably higher, tocopherol contents. Vegetables under glass grow rapidly and therefore would be expected to have lower contents of $\alpha$-tocopherol (Booth \& Hobson-Frohock, 1961) than those grown outdoors. Lettuce grows very fast, which may account for its tocopherol content being among the lowest for a leafy vegetable.

In general, dark-green leaves are richer than pale-green tissues in carotene, iron and other nutrients. In this respect tocopherol conforms (Booth, ${ }_{196} b$ ). On the other hand, tocopherol concentrations are low in fast-growing leaves, which are usually good sources of other vitamins; and, whereas carotene decreases (Booth, I945), tocopherol increases, in wilting leaves.

\section{Other tocopherols}

Tocopherols other than $\alpha$ commonly occur in seeds and some fruits. They were not detected in measurable amounts in most vegetables, although they have been found in this laboratory (Booth, $1962 a$ ) in high concentration in leaves of ivy (Hedera helix) and yew (Taxus baccata). On the other hand, some authors, for example Harris et al. (1950), who did not use paper chromatography, and whose values are commonly quoted in tables, have reported $\gamma$ - and $\delta$-tocopherol in some varieties of vegetables. The apparent discrepancy is therefore being investigated.

\section{SUMMARY}

I. Vegetables and fruits were analysed for $\boldsymbol{x}$-tocopherol. The lipids were extracted with acetone, and, without saponification, were run on a two-dimensional paper chromatogram whence tocopherol was removed for determination with $\mathrm{FeCl}_{3}$ and dipyridyl.

2. Blackberry and raspberry fruits were good sources of $\gamma$ - and $\delta$-tocopherol. Tocopherols other than $\alpha$ were not found in significant amounts in vegetables.

3. There was considerable variation in tocopherol content, not only between species and between different parts of a plant, but also between batches of the same material obtained from different sources or on different dates.

4. In many plants there was much less tocopherol in the 'edible part' than in the discarded portion. 
5. $\alpha$-Tocopherol contents were high in most dark-green tissues, e.g. mint and spinach; low to moderate in light-green tissues, e.g. lettuce, gooseberry, parsley stem and cress; and low in some roots, brassica flowers and some fruits, e.g. pear and apple.

6. $\alpha$-Tocopherol contents increased with maturity of the tissue.

We are grateful to Dr R. J. Ward for permitting us to include some of his results; and to the ARC Statistics Group for advice and for help with the statistics.

\section{REFERENCES}

Analytical Methods Committee (1959). Analyst, 84, 356.

Booth, V. H. (1945). F. Soc. chem. Ind., Lond., 64, 162.

Booth, V. H. (1959). Analyst, 84, 464.

Booth, V. H. (1961). Analyt. Chem. 33, 1224.

Booth, V. H. (1962a). Biochem. F. 84, 444 .

Booth, V. H. (1962 b). Biochem. F. 84, 85 P.

Booth, V. H. (1963a). Analyst, 88, 627.

Booth, V. H. (1963b). Phytochem. 2, 421 .

Booth, V. H. \& Bradford, M. P. (1963). Int. F. Vit. Res. 33, 276.

Booth, V. H. \& Hobson-Frohock, A. (196r). F. Sci. Fd Agric. 12, 25 I.

Emmerie, A. \& Engel, C. (I943). Z. Vitaminforsch. r3, 259.

Green, J., Marcinkiewicz, S. \& Watt, P. R. (1955). Ұ. Sci. Fd Agric. 6, 274.

Harris, P. L., Quaife, M. L. \& Swanson, W. J. (1950). F. Nutr. 40, 367.

McCance, R. A. \& Widdowson, E. M. (1960). Spec. Rep. Ser. med. Res. Coun., Lond., no. 297, p. I6z. 